\title{
Identifikasi Permasalahan Pemanfaatan Data Sebagai Dasar Pengambilan Keputusan Bisnis Pada UMKM Sektor Jasa: Kasus di Surabaya
}

\author{
Nisrina Arieza Rahmadita, Berto Mulia Wibawa, dan M. Saiful Hakim \\ Departemen Manajemen Bisnis, Fakultas Bisnis dan Manajemen Teknologi, Institut Teknologi Sepuluh \\ Nopember (ITS) \\ e-mail: berto@mb.its.ac.id
}

\begin{abstract}
Abstrak - UMKM jasa sangat berperan dalam pertumbuhan perekonomian Indonesia dan memiliki potensi besar untuk dikembangkan. Tujuan dari penelitian ini untuk mengetahui permasalahan yang mempengaruhi UMKM dalam memanfaatkan data sebagai dasar pengambilan keputusan bisnis. Penelitian ini merupakan penelitian exploratory-direct dengan teknik pengambilan data melalui in-depth interview dengan 2 narasumber yaitu satu pihak Dinas Perdagangan Kota Surabaya dan satu pihak UMKM di Surabaya. Hasil penelitian ini menghasilkan 18 masalah yang menyebabkan belum sepenuhnya UMKM sektor jasa di Surabaya memanfaatkan data sebagai dasar pengambilan keputusan bisnis.
\end{abstract}

Kata Kunci-Data, Fishbone, Pengambilan Keputusan, UMKM Jasa.

\section{PENDAHULUAN}

$\mathrm{U}$ SAHA Mikro, Kecil, dan Menengah (UMKM) di Indonesia merupakan salah satu bidang usaha yang berperan penting karena memiliki peranan bagi pertumbuhan ekonomi. Selain mempunyai peran penting bagi pertumbuhan ekonomi, UMKM juga berperan dalam penyerapan tenaga kerja dan distribusi hasil-hasil pembangunan. Pertumbuhan jumah unit UMKM pada tahun 2010 - 2013 mengalami peningkatan sebesar 2,6 persen setiap tahunnya dan rata-rata kontribusi UMKM terhadap Produk Domestik Bruto (PDB) Indonesia selama 3 tahun terakhir lebih dari 50 persen [1]. Hal ini membuktikan bahwa UMKM memiliki peran penting terhadap pertumbuhan ekonomi di Indonesia.

Salah satu sektor usaha yang diunggulkan oleh Bank Indonesia untuk mendorong pertumbuhan ekonomi adalah sektor jasa karena memiliki kontribusi yang meningkat terhadap perekonomian serta perdagangan indonesia [2]. Oleh karena itu, sektor jasa dapat menjadi masa depan Indonesia untuk meningkatkan pertumbuhan ekonomi serta daya saing Indonesia. Sektor jasa semakin berkembang setiap tahunnya seiring dengan berkembangnya gaya hidup dan inovasi dalam bisnis, kebutuhan hidup manusia yang mengarah pada kebutuhan yang praktis dan serba cepat membuat bisnis usaha jasa semakin berkembang dan inovatif.

UMKM memiliki karakter yang berbeda dengan usaha besar, kebanyakan pemilik UMKM mengambil keputusan berdasarkan dengan intuisi atau persepsi terhadap lingkungan bisnis. Dalam proses pengambilan keputusan strategis UMKM seringkali tanpa melalui perencanaan yang formal. UMKM tidak mengembangkan sebuah perencaan formal dan terhanyut dalam situasi yang ada [3]. UMKM jasa harus melakukan pembaharuan mindset dengan beralih kepada pemanfaatan data untuk mengembangkan bisnisnya dan melihat kondisi pasar [4]. Maka dari itu, tujuan dari penelitian ini ntuk mengidentifikasi permasalahan yang dihadapi dalam pemanfaatan data sebagai dasar pengambilan keputusan pada UMKM sektor jasa di Surabaya.

\section{LANDASAN TEORI}

\section{A. Usaha Mikro, Kecil, dan Menengah (UMKM)}

Di Indonesia, pengertian dan kriteria UMKM diatur dalam Undang-Undang Nomor 20 Tahun 2008 yang menyatakan bahwa UMKM adalah sebuah perusahaan yang digolongkan sebagai perusahaan kecil yang dimiliki dan dikelola oleh seseorang atau dimiliki oleh sekelompok kecil orang dengan jumlah kekayaan dan pendapatan tertentu. Kriterita UMKM di Indonesia terdiri dari tiga, yaitu (1) kriteria usaha mikro, (2) kriteria usaha kecil, dan (3) kriteria usaha menengah [5].

Tabel 1.

Kriteria UMKM di Indonesia Sesuai UU No. 20 Tahun 2008

\begin{tabular}{lll}
\hline \hline \multicolumn{1}{c}{ Jenis Usaha } & Jumlah Kekayaan Bersih* & \multicolumn{1}{c}{$\begin{array}{c}\text { Hasil Penjualan } \\
\text { Tahunan }\end{array}$} \\
\hline Usaha Mikro & Maksimal Rp 50 juta & $\begin{array}{l}\text { Maksimal Rp 300 juta } \\
\text { >Rp 300 juta - Rp 2,5 } \\
\text { miliar }\end{array}$ \\
Usaha Kecil & $>$ Rp 50 juta - Rp 500 juta & $\begin{array}{l}\text { >Rp 2,5 miliar - Rp } \\
\text { Usaha }\end{array}$ \\
Menengah & >Rp 500 juta - Rp 10 & miliar miliar \\
\hline \hline
\end{tabular}

*Tidak termasuk tanah dan bangunan usaha

\section{B. Jasa}

Salah satu sektor UMKM yang menjadi perhatian pada penelitian ini adalah sektor jasa. Pengertian jasa didefinisikan sebagai sebuah kegiatan ekonomi yang ditawarkan pada sebuah pihak ke pihak lain, tanpa memindahkan kepemilikan, menciptakan sebuah nilai, dari menyewakan sesuatu atau memberikan akses kepada benda, tenaga kerja, kemampuan profesional, fasilitas, jaringan, atau sistem secara sendiri atau kombinasi dari itu [6].

\section{Pengambilan Keputusan (Decision Making)}

Dalam Kamus Besar Ilmu Pengetahuan, pengambilan keputusan (decision making) didefinisikan sebagai pemilihan keputusan atau kebijakan yang berdasarkan pada kriteria tertentu. Dasar-dasar pengambilan keputusan antara lain terbagi menjadi tiga yaitu intuisi, pengalaman, dan fakta, data, dan informasi [7].

\section{Data}

Salah satu dasar pengambilan keputusan adalah melalui data. Pentingnya data dalam pengambilan keputusan adalah 
sebagai pedoman atau dasar yang dapat digunakan untuk mengambil keputusan yang tepat. Data adalah deskripsi dasar dari benda, peristiwa, aktivitas, dan transaksi yang direkam, dikelompokkan, dan disimpan [8].

\section{E. Information and Communication Technology (ICT)}

Salah satu sarana untuk memperoleh, mengumpulkan, dan memanfaatkan data adalah ICT. ICT merupakan teknologi yang mencakup semua sarana teknis yang digunakan untuk memperoleh data, menangani informasi, dan memfasilitasi alat komunikasi, termasuk komputer, perangkat jaringan keras, jalur komunikasi, dan semua perangkat lunak yang diperlukan. Tipe-tipe ICT yang digunakan dalam melakukan records information pada UMKM adalah mobile phone, e-mail, website, spreadsheetexcel, social networking, scanner, printer, database software, digital video camera, storage device, photocopy machine, computer, e-commerce [9].

\section{METODE PENELITIAN}

\section{A. Desain Penelitian}

Penelitian ini menggunakan pendekatan riset deskriptif dimana memiliki tujuan utama yaitu untuk mengidentifikasi permasalahan yang dihadapi dalam pemanfaatan data sebagai dasar pengambilan keputusan pada UMKM sektor jasa di Surabaya. Data yang diambil dalam penelitian ini adalah data primer dengan melakukan wawancara kepada pihak Dinas Perdagangan Kota Surabaya dan pihak UMKM sektor jasa.

\section{B. Objek Penelitian}

Penelitian ini dilakukan kepada Pihak Dinas Perdagangan dan pelaku UMKM sektor jasa di Surabaya yang dipilih menggunakan metode purposive sampling, responden dipilih berdasarkan beberapa kriteria yaitu bagi Dinas yang menaungi UMKM di Surabaya dan bagi pelaku UMKM yaitu telah beroperasi di Surabaya lebih dari 20 tahun.

\section{Metode Analisis Data}

Analisis fishbone merupakan suatu alat yang digunakan untuk menganalisis masalah dan faktor-faktor yang menyebabkan masalah tersebut. Diagram ini merupakan suatu pendekatan yang memungkinkan suatu analisis dilakukan suatu pendekatan yang memungkinkan suaru analisis dilakukan untuk menemukan penyebab suatu masalah. Selain itu juga digunakan untuk mengidentifikasi sebab dari masalah yang terjadi dalam sebuah proses penggunaan dan gambaran perbaikan.

Dalam penelitian ini digunakan pendekatan 8P yang biasa digunakan dalam industri jasa yaitu masalah dikategorikan menjadi delapan kategori sesuai dengan proses bisnis yang berlaku dalam UMKM. Delapan kategori tersebut adalah price, people, place, promotion, processes, product, physical evidence, dan productivity \& quality. Berikut merupakan gambaran diagram fishbone yang digunakan dalam penelitian:

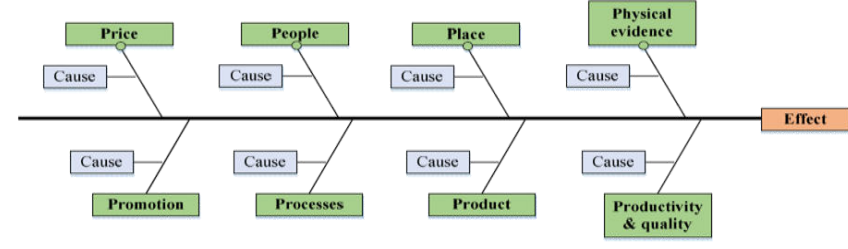

Gambar 1. Diagram Fishbone Pendekatan 8P [10].

a. People

Merupakan manusia yang terlibat dalam kegiatan produksi sebuah produk atau layanan hingga kegiatan penyampaian produk atau layanan hingga ke tangan konsumen.

\section{b. Physical Evidence}

Merupakan perangkat berupa bukti fisik yang dibutuhkan dalam penyampaian dan penyajian jasa dalam bentuk nyata oleh perusahaan.

c. Place

Merupakan tempat dan bagaimana sebuah usaha menyajikan jasa yang baik kepada konsumen.

\section{d. Process}

Merupakan suatu metode pengoperasian atau serangkaian tindakan yang diperlukan untuk menyajikan produk atau jasa yang ditawarkan oleh perusahaan kepada konsumen.

\section{e. Product}

Merupakan suatu komponen dari hasil pengerjaan jasa yang ditawarkan oleh perusahaan kepada konsumen dengan memberikan nilai dan manfaat, memenuhi kebutuhan, dan dapat memuaskan konsumen.

\section{f. Price}

Merupakan biaya, waktu, dan usaha yang dikorbankan oleh perusahaan dalam memproduksi dan menyajikan jasa yang dikeluarkan dalam menggunakan data.

\section{g. Promotion}

Merupakan aktivitas komunikasi dan penyaluran informasi untuk membangun persepsi pelanggan terhadap usaha jasa yang diberikan oleh perusahaan.

h. Productivity \& Quality

Merupakan ukuran efisiensi layanan yang ditransformasikan ke dalam hasil-hasil jasa yang mampu menambah nilai bagi konsumen (produktivitas) dan derajat suatu layanan yang mampu memenuhi harapan konsumen (kualitas).

\section{ANALISIS DAN DISKUSI}

\section{A. Analisis Data}

UMKM memiliki peranan bagi pertumbuhan ekonomi. Selain mempunyai peran penting bagi pertumbuhan ekonomi, UMKM juga berperan dalam penyerapan tenaga kerja dan pendistribusian hasil-hasil pembangunan. Salah satu sektor usaha yang sedang diunggulkan oleh Bank Indonesia untuk mendorong pertumbuhan ekonomi adalah sektor jasa. Dilihat pada lingkungan sekitar terutama di kota Surabaya, masih banyak UMKM sektor jasa yang belum mampu dalam mengumpulkan, mengolah, dan memanfaatkan data sebagai dasar pengambilan keputusan. Hal tersebut berdampak pada kemajuan dan daya saing pelaku UMKM di Kota Surabaya sendiri. Penelitian ini menggunakan pendekapan $8 \mathrm{P}$ yang biasa digunakan dalam industri jasa yaitu masalah dikategorikan menjadi 8 kategori 
yaitu price, people, place, promotion, processes, product, physical evidence, dan productivity \& quality.

Data diperoleh melalui wawancara dengan Pihak Dinas Perdagangan Kota Surabaya di wakilkan oleh Bu Nurul dan Mbak Laily selaku staf Bidang Pemasaran Dinas Perdagangan Kota Surabaya, sedangkan untuk pihak
UMKM diwakili oleh Bu Sri yang telah menjalankan usaha Fotokopi selama 22 tahun di daerah Surabaya Selatan. Berikut merupakan hasil analisis permasalahan yang dialami oleh pihak UMKM dalam pemanfaatan data sebagai dasar pengambilan keputusan bisnis (Gambar 2).

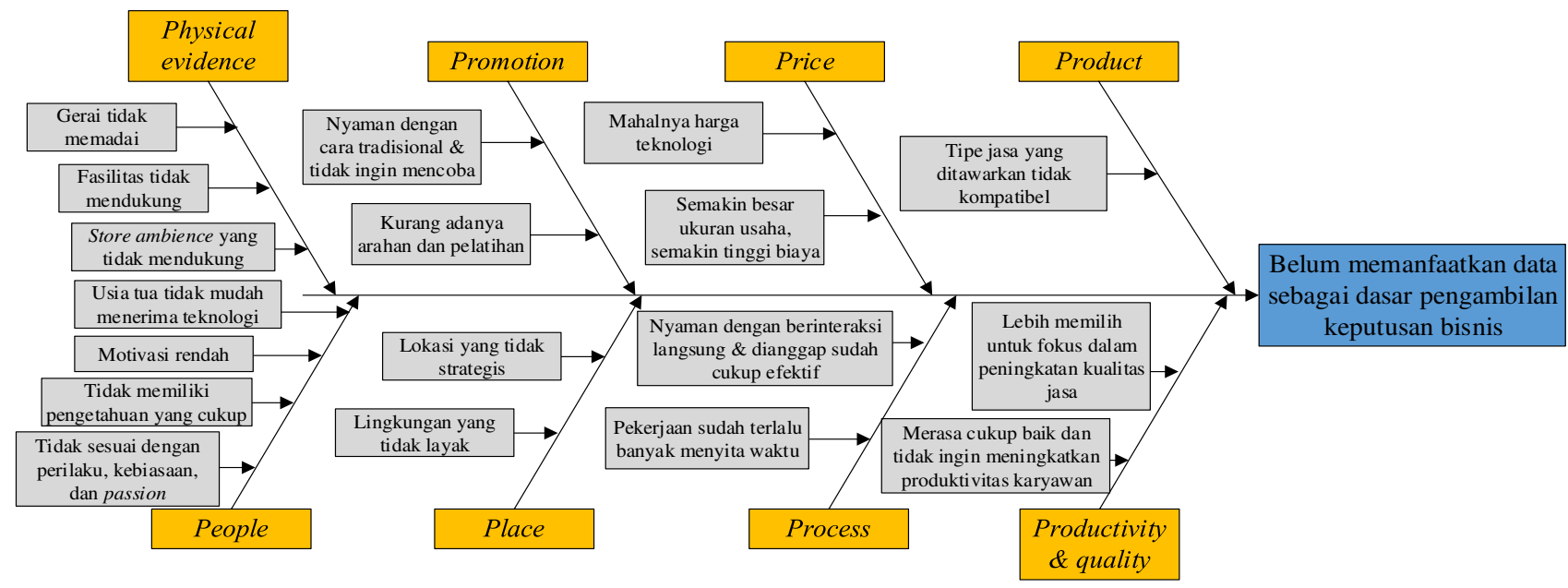

Gambar 2. Hasil Analisis Fishbone.

1. People

a. Usia tua tidak mudah menerima teknologi

Pelaku usaha dengan usia yang memasuki generasi X (kelahiran tahun 1965 - 1980) keatas tidak memanfaatkan data dan lebih memilih untuk menggunakan pengalaman serta intuisi dalam pengambilan keputusan serta cenderung hanya menunggu pelanggan tanpa membuat sebuah strategi bisnis.

\section{b. Motivasi rendah}

Masalah yang paling sering dihadapi oleh pelaku UMKM sektor jasa di Surabaya adalah rendahnya motivasi serta keinginan untuk belajar dan menjadi lebih maju, banyak dijumpai ketika sebuah teknologi mudah dijangkau dan mudah diterapkan, namun pihak pelaku usaha tidak menerapkan karena tidak ada kemauan untuk mempelajari teknologi tersebut.

c. Tidak memiliki pengetahuan yang cukup

Pengetahuan memiliki pengertian yang luas dalam hal ini; wawasan, pengetahuan teknologi, tingkat pendidikan terakhir, dan pola pikir pelaku UMKM sektor jasa. Mayoritas pelaku UMKM sektor jasa di Kota Surabaya tidak menggunakan data sebagai dasar pengambilan keputusan adalah karena mereka tidak memiliki pengetahuan dalam memanfaatkan hingga cara mengoperasikan teknologi.

d. Tidak sesuai dengan perilaku, kebiasaan, dan passion

Perilaku, kebiasaan, dan passion pelaku terhadap penggunaan teknologi dalam memanfaatkan data sebagai dasar pengambilan keputusan bisnis dapat mempengaruhi keputusan pelaku UMKM sektor jasa di Kota Surabaya dalam memanfaatkan data. Apabila dalam diri pelaku tidak ada ketertarikan atau kebiasaan dalam menggunakan teknologi maka mereka tidak akan menerapkan hal tersebut pada usaha mereka.

\section{Physical Evidence}

a. Gerai tidak memadai

Gerai yang tidak memadai dapat dicontohkan seperti gerai usaha yang sempit, kecil, dan tidak memungkinkan untuk di beri tambahan ruang untuk sebuah teknologi yang dapat digunakan sebagai alat pemanfaatan data sebagai dasar pengambilan keputusan bisnis.

\section{b. Fasilitas tidak mendukung}

Penggunaan teknologi berkaitan dengan penggunaan internet maupun listrik, apabila suatu usaha tidak memiliki fasilitas seperti internet maupun listrik, maka akan sulit usaha tersebut untuk menggunakan berbagai teknologi dalam pemanfaatan data, terlebih dalam pengambilan keputusan bisnisnya.

c. Store ambience yang tidak mendukung

Apabila suasana dilingkungan sekitar tidak mendukung seperti suasana perkampungan yang kumuh atau ramai tidak kondusif maka akan sulit pemilik usaha untuk memanfaatkan data sebagai dasar pengambilan keputusan.

3. Process

a. Nyaman dengan interaksi langsung dan menganggap proses saat ini sudah cukup efektif

Penyedia jasa lebih mudah mengetahui keinginan dan permintaan pelanggan melalui interaksi langsung, selain lebih mudah, dengan berinteraksi langsung terhadap konsumen dapat mendekatkan hubungan antara penyedia jasa dan pelanggan secara tidak langsung.

b. Pekerjaan sudah terlalu banyak menyita waktu

Dalam pengoperasian teknologi sebagai alat pemanfaatan data sebagai dasar pengambilan keputusan bisnis, akan sangat membutuhkan waktu ekstra dalam pengerjaannya, maka dari itu, para penyedia jasa tidak memiliki cukup waktu dalam mengoperasikan berbagai teknologi.

\section{Product}

Masalah yang sering terjadi adalah seperti tipe jasa yang ditawarkan tidak kompatibel contohnya seperti penjahit dan salon rambut yang selalu mengikuti model saat ini, sehingga para penyedia jasa tersebut harus update mengenai model terbaru melalui internet. Namun sebaliknya, penyedia jasa seperti duplikat kunci tidak membutuhkan komputer atau 
internet untuk mengetahui model terbaru dan lain sebagainya.

\section{Place}

a. Lokasi tidak strategis

Lokasi usaha yang tidak strategis membuat usaha tersebut tidak banyak dikunjungi oleh pelanggan, terlebih dengan jauhnya tempat usaha dengan target pasar. Sehingga hal tersebut akan mempersulit pelaku UMKM sektor jasa di Kota Surabaya untuk memanfaatkan data sebagai dasar pengambilan keputusan bisnis.

\section{b. Lingkungan tidak layak}

Lingkungan usaha yang tidak layak atau tidak memadai juga menjadi penyebab pelaku UMKM sulit memanfaatkan data sebagai dasar keputusan bisnis. Ketika suatu usaha berada pada lokasi yang tidak layak ataupun tidak memadai maka usaha tersebut tidak akan dapat memanfaatkan data. Tidak layaknya tempat atau tidak memadainya suatu usaha untuk berdiri di Surabaya dapat berasal dari berbagai faktor seperti lingkungan usaha, suasana, dll.

6. Price

a. Mahalnya biaya teknologi

Pemanfaatan data sebagai dasar pengambilan keputusan bisnis pada UMKM sektor jasa juga membutuhkan biaya yang tinggi, contohnya dalam pemanfaatan data, penyedia jasa membutuhkan komputer, internet, ponsel android, dan lain sebagainya sebagai sarana pengumpulan, pengolahan, dan pemanfaatan data sebagai dasar pengambilan keputusan.

b. Semakin besar ukuran usaha, semakin tinggi biaya

Semakin besar ukuran dan skala usaha, semakin tinggi pula teknologi yang digunakan, sehingga menyebabkan semakin tingginya biaya yang dibutuhkan. Meskipun tipe jasa yang diberikan memiliki kesamaan, namun dengan ukuran dan skala usaha yang berbeda dapat mempengaruhi kegiatan pemanfaatan data sebagai dasar pengambilan keputusan.

\section{Promotion}

a. Nyaman dengan cara tradisional \& tidak ingin mencoba

Salah satu permasalahan terberat dalam pemanfaatan data sebagai dasar pengambilan keputusan bisnis ialah para penyedia jasa lebih nyaman menggunakan cara tradisional atau manual dalam pengambilan keputusan bisnis, yaitu hanya berpaku pada pengalaman dan intuisi.

b. Kurang adanya arahan dan pelatihan

Dalam melakukan kegiatan pemanfaatan data sebagai dasar pengambilan keputusan terutama pada bagian pemasaran, dibutuhkannya kemampuan dan pengetahuan mengenai cara memasarkan sebuah jasa dengan baik dan benar. Namun ditemukan permasalahan bahwa pelaku UMKM sektor jasa di Kota Surabaya masih sedikit yang mendapatkan dukungan dari pihak eksternal atau pihak Dinas Pemerintahan seperti sosialisasi dan pelatihan seputar pemanfaatan data sebagai dasar pengambilan keputusan.

\section{Productivity \& Quality}

a. Lebih memilih untuk fokus dalam peningkatan kualitas jasa

Selama ini, pelaku UMKM sektor jasa di Kota Surabaya hanya menfokuskan kualitas jasa yang akan diberikan pada pelanggan dengan harapan pelanggan menjadi puas dan akan melakukan pembelian kembali tanpa menfokuskan pada keputusan bisnis yang sebenarnya bermanfaat bagi kemajuan usaha tersebut dalam jangka panjang. b. Merasa cukup baik dan tidak ingin meningkatkan produktivitas karyawan

Dengan ada atau tanpa adanya data sebagai dasar pengambilan keputusan bisnis, pelaku UMKM sektor jasa di Kota Surabaya saat ini meyakini bahwa produktivitas kerja karyawan yang mereka miliki dianggap cukup baik sehingga tidak membutuhkan penggunaan data sebagai dasar pengambilan keputusan bisnis.

\section{B. Diskusi}

Fishbone disusun berdasarkan jumlah masalah dari kiri ke kanan, dari masalah terbanyak hingga masalah paling sedikit. Masalah terbanyak adalah kategori people yang memiliki 4 masalah, kategori physical evidence yang memiliki 3 masalah, kategori place, product, price, process, promotion, dan productivity \& quality yang memiliki 2 masalah berdasarkan hasil wawancara.

\section{Implikasi Manajerial}

Terdapat 7 implikasi manajerial yang dapat diaplikasikan pada UMKM, Pemerintahan Pusat, Pemerintahan Provinsi, Pemerintahan Kota Surabaya, dan investor berdasarkan analisis masalah yang sering terjadi dalam pemanfaatan data sebagai dasar pengambilan keputusan bisnis pada UMKM sektor jasa di Surabaya.

Kepada pelaku UMKM sektor jasa dapat diaplikasikan pembuatan kembali business model usaha guna mengetahui kondisi saat ini dan rencana perbaikan bisnis kedepannya serta kooperatif dengan penyedia jasa sejenis untuk melakukan merger dalam sharing aset usaha guna saling mengembangkan bisnisnya menjadi lebih baik dan mampu memanfaatkan data dengan baik pula.

Kepada Pemerintah Pusat, Pemerintah Provinsi, dan Pemerinta Kota Surabaya dapat mengaplikasikan pemberian pelatihan mengenai teknologi yang paling sesuai dan fit pada bidang jasa yang disediakan agar mampu memanfaatkan data sebagai dasar pengambilan keputusan bisnis dengan mudah. Memberikan keringanan biaya berupa regulasi yang dapat memberikan keuntungan oleh pelaku UMKM dalam meninkmati fasilitas yang dapat mendukung penggunaan teknologi pada usahanya seperti regulasi akan biaya internet, pulsa, dan lain-lain. Memberikan sosialisasi secara rutin untuk menyalurkan informasi mengenai pentingnya pemanfaatan data sebagai dasar pengambilan keputusan bisnis serta menyusun peta konsep kebutuhan \& strategi kompetensi pelaku UMKM sektor jasa di Kota Surabaya.

Selain itu, mampu menyediakan program atau fasilitas terintegrasi yang mampu menampung berbagai macam usaha dari seluruh kategori dan bidang usaha untuk mendukung kegiatan pemanfaatan data sebagai dasar pengambilan keputusan bisnis seperti website terintegrasi dari pemerintah, hal ini juga dapat diaplikasikan oleh investor yang ingin menginvestasikan bisnisnya dalam membantu pengembangan UMKM sektor jasa di Surabaya.

\section{SIMPULAN DAN SARAN}

\section{A. Simpulan}

Terdapat 18 masalah yang menyebabkan UMKM sektor jasa tidak memanfaatkan data sebagai dasar pengambilan keputusan bisnis yang dapat diidentifikasi dan dikelompokan kedalam 8 kategori berdasarkan pendekatan $8 \mathrm{P}$ dari hasil wawancara. 


\section{B. Limitasi dan Saran}

Penelitian ini dilakukan pada bulan November hingga Desember tahun 2017 sehingga hasil dari penelitian ini menggambarkan perilaku UMKM sektor jasa pada bulan tersebut. Pada penelitian selanjutnya, disarankan untuk melakukan benchmark dan mengeneralisir hasil penelitian dengan UMKM di kota lain di Indonesia yang memiliki karakter dan perilaku pelaku usaha yang sama dengan Surabaya.

\section{DAFTAR PUSTAKA}

[1] Dinas Koperasi dan UMKM Jawa Timur, "Data UMKM," 2016 [Online]. Available: http://diskopumkm.jatimprov.go.id/viewmedia.php?pages $=$ content\&id $=57 \&$ bidang $=$.

[2] R. Chaves, "Ekonomi: Bank Dunia: Sektor Jasa Berpotensi Dorong Pertumbuhan Ekonomi Indonesia," Republika.co.id, 2017. [Online]. Available: http://www.republika.co.id.
Netherland: Scientific Analysis of Entrepreneurship and SMEs, 2003.

[4] B. Wibawa, New Venture Creation : Start Your Business Module Serang: CV. Sinar Gamedia, 2017.

[5] Bank Indonesia, "Undang-Undang Republik Indonesia No 20 Tahun 2008," 2008

[6] Lovelock and et al, Essentials of Service Marketing. Jurong: Pearson Education, 2012.

[7] I. Syamsi, Pengambilan keputusan dan Sistem Informasi. Jakarta: Bumi Aksara, 2000.

[8] E. Turban and L. Volonino, Information Technology for Management, 7th ed. Asia: John Willey \& Sons, Inc, 2010.

[9] O. Obura, "Utilisation of ICT by SMEs in records and information management in Uganda: a baseline study," J. South Africa Soc. Achivists, vol. 44, pp. 43-66, 2011.

[10] R. O. Putri and B. M. Wibawa, "Identifikasi Permasalahan Komplain pada E-Commerce Menggunakan Metode Fishbone,' J. Sains dan Seni ITS, vol. 6, no. 1, pp. 37-41, 2017. 